\title{
iTRAQ-Based Quantitative Proteomic Analysis of Intestines in Murine Polymicrobial Sepsis with Hydrogen Gas Treatment
}

This article was published in the following Dove Press journal:

Drug Design, Development and Therapy

\author{
Yi Jiang ${ }^{1,2, *}$ \\ Yingxue $\operatorname{Bian}^{3, *}$ \\ Naqi Lian ${ }^{1,2}$ \\ Yaoqi Wang ${ }^{1,2}$ \\ Keliang $\mathrm{Xie}^{1,2}$ \\ Chao Qin (1D ${ }^{1,2}$ \\ Yonghao $\mathrm{Yu}^{1,2}$ \\ 'Department of Anesthesiology, Tianjin \\ Medical University General Hospital, \\ Tianjin, People's Republic of China; \\ ${ }^{2}$ Tianjin Institute of Anesthesiology, \\ Tianjin, People's Republic of China; \\ ${ }^{3}$ Department of Anesthesiology, Tianjin \\ Union Medical Center, Tianjin, People's \\ Republic of China
}

*These authors contributed equally to this work
Correspondence: Yonghao Yu; Chao Qin Department of Anesthesiology, Tianjin Medical University General Hospital, No. I54 Anshan Road, Heping District, Tianjin 300052, People's Republic of China Email yuyonghao@126.com; qinchao0828@I26.com
Objective: Sepsis-associated intestinal injury has a higher morbidity and mortality in patients with sepsis, but there is still no effective treatment. Our research team has proven that inhaling $2 \%$ hydrogen gas $\left(\mathrm{H}_{2}\right)$ can effectively improve sepsis and related organ damage, but the specific molecular mechanism of its role is not clear. In this study, isobaric tags for relative and absolute quantitation (iTRAQ)-based quantitative proteomics analysis was used for studying the effect of $\mathrm{H}_{2}$ on intestinal injury in sepsis.

Methods: Male C57BL/6J mice were used to prepare a sepsis model by cecal ligation and puncture (CLP). The 7-day survival rates of mice were measured. 4-kd fluorescein isothiocyanateconjugated Dextran (FITC-dextran) blood concentration measurement, combined with hematoxylin-eosinstain (HE) staining and Western blotting, was used to study the effect of $\mathrm{H}_{2}$ on sepsisrelated intestinal damage. iTRAQ-based liquid chromatography-tandem mass spectrometry (LCMS/MS) analysis was used for studying the proteomics associated with $\mathrm{H}_{2}$ for the treatment of intestinal injury.

Results: $\mathrm{H}_{2}$ can significantly improve the 7-day survival rates of sepsis mice. The load of blood and peritoneal lavage bacteria was increased, and $\mathrm{H}_{2}$ treatment can significantly reduce it. CLP mice had significant intestinal damage, and inhalation of $2 \%$ hydrogen could significantly reduce this damage. All 4194 proteins were quantified, of which 199 differentially expressed proteins were associated with the positive effect of $\mathrm{H}_{2}$ on sepsis. Functional enrichment analysis indicated that $\mathrm{H}_{2}$ may reduce intestinal injury in septic mice through the effects of thyroid hormone synthesis and nitrogen metabolism signaling pathway. Western blot showed that $\mathrm{H}_{2}$ was reduced by downregulating the expressions of deleted in malignant brain tumors 1 protein (DMBT1), insulin receptor substrate 2 (IRS2), N-myc downregulated gene 1 (NDRG1) and serum amyloid A-1 protein (SAA1) intestinal damage in sepsis mice.

Conclusion: A total of 199 differential proteins were related with $\mathrm{H}_{2}$ in the intestinal protection of sepsis. $\mathrm{H}_{2}$-related differential proteins were notably enriched in the following signaling pathways, including thyroid hormone synthesis signaling pathway, nitrogen metabolism signaling pathways, digestion and absorption signaling pathways (vitamins, proteins and fats). $\mathrm{H}_{2}$ reduced intestinal injury in septic mice by down-regulating the expressions of SAA1, NDRG1, DMBT1 and IRS2.

Keywords: sepsis, intestinal injury, hydrogen gas, proteomics, isobaric tags for relative and absolute quantitation, iTRAQ

\section{Introduction}

Sepsis is a harmful host response, which is caused by a series of pathophysiological processes such as the excessive release of inflammatory factors and the 
imbalance between anti-inflammatory and proinflammatory responses, and then develops into multipleorgan dysfunction syndrome (MODS) and/or tissue hypoperfusion. ${ }^{1}$ Because of its high incidence and mortality, it has become one of the top ten causes of death in the intensive care unit in the United States, ${ }^{2}$ but there is still no effective treatment. The intestine plays a key role in various pathophysiology of sepsis. ${ }^{3}$ The intestinal mucosal barrier consists of connections between intestinal epithelial cells and adjacent cells, which can effectively prevent intestinal bacteria and endotoxins from invading the human body. ${ }^{4}$ However, under the conditions of inflammatory response and oxidative stress, the structure and function of the intestinal mucosa are damaged, and the permeability of the intestinal wall is increased, causing intestinal bacterial translocation. ${ }^{5}$

Hydrogen gas $\left(\mathrm{H}_{2}\right)$, as the most widespread gas in the universe, has been identified as a therapeutic medical gas for many diseases due to its antioxidant, anti-inflammatory and anti-apoptotic effects. ${ }^{6}$ Earlier studies by our group have shown that $2 \%$ hydrogen inhalation has a significant relief and therapeutic effect on sepsis and multiple organ damage related to sepsis including lung, brain and intestine. ${ }^{7-9}$ In addition, it has been demonstrated that $\mathrm{H}_{2}$ can also prevent intestinal damage caused by sepsis in vitro. ${ }^{10}$ However, to date, the specific mechanism of $\mathrm{H}_{2}$ treatment remains unknown.

Due to the continuous update of molecular biology technology, proteomics analysis has become a highly effective screening technology for comprehensive evaluation of protein expressions in complex specimens and has been broadly used in numerous research areas. ${ }^{11}$ One of the quantitative proteomics technologies is relative quantitative and absolute quantitative isobaric labeling (iTRAQ), which can perform multiple relative quantification of proteins by mass spectrometry. ${ }^{12}$ Previously, our group confirmed that the proteome of sepsis lung tissue is significantly different from that of normal lung tissue. ${ }^{12}$ In this study, iTRAQ technology was used in combination with liquid chromatography-tandem mass spectrometry (LC-MS/MS) to study differentially expressed proteins in the intestine of $\mathrm{H}_{2}$ treated sepsis mice to further explore the molecule mechanism of $\mathrm{H}_{2}$ in the positive role of sepsis.

\section{Materials and Methods}

\section{Ethics}

All experimental protocols were approved by the Institutional Animal Care and Use Committee of Tianjin
Medical University General Hospital, and were conducted in accordance with the National Institutes of Health Guide for the Care and Use of Laboratory animals.

\section{Animals and Experimental Design}

Adult male C57BL/6J mice, weighing 23 to $28 \mathrm{~g}$, 8 weeks old, were purchased from the Experimental Animal Center of the Academy of Military Medical Sciences (Beijing, China). Mice were given water and food under a controllable environment (temperature $22 \sim 25{ }^{\circ} \mathrm{C}$, humidity $45 \% \sim 55 \%, 12: 12 \mathrm{~h}$ light-dark cycle). In this study, all 360 mice were randomly divided into four groups $(\mathrm{n}=$ 72 per group): Sham, Sham $+\mathrm{H}_{2}$, Sepsis, and Sepsis $+\mathrm{H}_{2}$. Sepsis mice were created by cecal ligation and puncture (CLP). $2 \% \mathrm{H}_{2}$ was inhaled for 1 hbeginning at both $1 \mathrm{st}$ and 6 th hour after sham or CLP operation in Sham $+\mathrm{H}_{2}$ or Sepsis $+\mathrm{H}_{2}$ group. Eighty mice were applied to assess the 7-day survival rates ( $\mathrm{n}=20$ per group), 24 mice were sacrificed for the bacterial load quantification ( $n=6$ per group), 24 mice were employed for the hematoxylineosinstain (HE) staining ( $\mathrm{n}=6$ per group), 96 mice were applied for intestinal tight junction barrier permeability at 4 time points ( $n=6$ per group), 40 mice were used for intestinal proteomics analysis ( $\mathrm{n}=10$ per group), 72 mice were sacrificed for intestinal tight junction protein by Western blot at 3 time points ( $\mathrm{n}=6$ per group) and 24 mice were sacrificed to verify $\mathrm{H}_{2}$-related differential protein by Western blot ( $n=6$ per group). The 7-day survival rates were calculated after Sham or CLP operation.

\section{CLP Model}

Cecal ligation and perforation (CLP) was performed on the basis of the method of previous study. ${ }^{7}$ Animals need to fast for 8 hduring which they drink water freely. Mice were induced into an anesthetic state by intraperitoneally injecting $2 \%$ sodium pentobarbital $(50 \mathrm{mg} / \mathrm{kg}$ ) diluted with saline. Hair on mice abdomen was shaved and a $1 \mathrm{~cm}$ midline abdominal incision was made with the aim of exposing the cecum. The cecum was ligated with a 3-0 silk thread at the distal end of the ileocecal valve. The cecum distal to the point of ligation was punctured with a 20-gauge needle, and the feces was squeezed out through the puncture point, and then the cecum was put to the peritoneal cavity gently. The incision was sutured with a sterile 3-0 silk absorbable suture. The mice of Sham and Sham $+\mathrm{H}_{2}$ groups received laparotomy without CLP. Normal saline $(1 \mathrm{~mL})$ was given subcutaneously to all mice after operation. 


\section{$\mathrm{H}_{2}$ Treatment}

Based on depiction of our previous method, ${ }^{7}$ the animals were placed in a leaktight plexiglass box with an air inlet and an outlet. $\mathrm{H}_{2}$ was generated through the TF-1 gas flowmeter (YUTAKA Engineering Corp) at a speed of 4 $\mathrm{L} / \mathrm{min}$ and then mixed with air into the box. The concentration of $\mathrm{H}_{2}$ was continuously monitored by a detector (HY-ALERTA Handheld Detector Model 500, $\mathrm{H}_{2}$ Scan). Baralyme (Chemetron Medical Division, Allied Healthcare Products, Inc., St. Louis, MO, USA) removed carbon dioxide produced by animals. The mice were given $2 \% \mathrm{H}_{2}$ treatment for 1 hbeginning at both 1 st and 6 th hour after Sham or CLP operation. In the meantime the mice in Sham or Sepsis groups were set inside the identical container with air inhalation.

\section{Survival Rates}

The survival rates of all groups were evaluated within 7 days after the procedure and all the experiments were repeated.

\section{Sample Collection}

The mice in different groups were induced into a deep anesthetic state $24 \mathrm{~h}$ after Sham or CLP operation. Two $\mathrm{mL}$ of sterile phosphate buffered saline (PBS) were injected into the abdominal cavity. Then the incision of abdomen was made and the peritoneal lavage was collected. Next, the thoracic cavity of mice was exposed and the cardiac chamber was pierced by utilizing a sterile 18 gauge needle. The blood was gathered with a heparinized syringe. After the right auricle was pierced, isotonic saline was injected into left ventricle to clear blood away. The mice were sacrificed for intestinal tissue. A part of intestinal sample was ground in $1 \mathrm{~mL} 0.9 \%$ sterile normal saline and the bacterial load was quantified. Using liquid nitrogen, the other part of intestinal sample was quickly frozen, and the specimen was kept in $-80{ }^{\circ} \mathrm{C}$ refrigerator for subsequent analysis. Five samples of each group were blended as one sample for analysis in order to avoid the individual differences. All 8 samples of 4 groups (10 biological replicates and 2 technical replicates) were disposed by iTRAQ-based quantitative proteomic analysis.

\section{Bacterial Load Quantification}

The blood and peritoneal lavage of mice were mixed with sterile PBS (1:10). The bacteria in each group of $100 \mu \mathrm{L}$ dilution were planted on $5 \%$ goat blood agar plates (Becton, Dickinson Company, Germany). The plates were cultivated at $37^{\circ} \mathrm{C}$ in a cell incubator for $24 \mathrm{~h}$. The number of colony-forming units (CFU) was calculated.

\section{HE Staining}

Intestinal specimens were collected immediately after mice sacrifice. The intestines were immersed in $4 \%$ paraformaldehyde for $24 \mathrm{~h}$, stained with hematoxylin and eosin after dehydration, embedded and sliced. The structural and morphological changes were observed and analyzed by a OLYMPUS BX51 microscope. Histological score was determined by multiplying the percent involvement for the following histologic characteristics namely inflammation severity, extent of inflammation and crypt damage by the $\%$ area of involvement (Table 1). ${ }^{13}$

\section{Intestinal Tight Junction Barrier}

Mice were fasted without water deprived $4 \mathrm{~h}$ before gavage. At the first $30 \mathrm{~min}$ of $90,180,360$ and $720 \mathrm{~min}$, $50 \mathrm{mg} / \mathrm{mL}$ 4-kd fluorescein isothiocyanate-conjugated Dextran (FITC-Dextran; Sigma Chemicals) were gavaged at $4 \mu \mathrm{L} / \mathrm{g}$ body weight through an 18 -gauge stainless steel

Table I Criteria Used to Determine Small Intestine Histology Score

\begin{tabular}{|c|c|c|}
\hline $\begin{array}{l}\text { Histological } \\
\text { Parameter }\end{array}$ & Criteria & Grade \\
\hline Inflammation severity & $\begin{array}{l}\text { None } \\
\text { Minimal } \\
\text { Moderate } \\
\text { Severe }\end{array}$ & $\begin{array}{l}0 \\
1 \\
2 \\
3\end{array}$ \\
\hline Extent of inflammation & $\begin{array}{l}\text { None } \\
\text { Mucosa } \\
\text { Mucosa and Submucosa } \\
\text { Severe } \\
\text { Transmural }\end{array}$ & $\begin{array}{l}0 \\
1 \\
2 \\
3 \\
4\end{array}$ \\
\hline Crypt damage & $\begin{array}{l}\text { None } \\
\text { One third of crypt damage } \\
\text { Two third of crypt damage } \\
\text { Crypts loss, surface epithelium } \\
\text { intact } \\
\text { Crypts loss, surface epithelium } \\
\text { lost }\end{array}$ & $\begin{array}{l}0 \\
1 \\
2 \\
3 \\
4\end{array}$ \\
\hline$\%$ Area involvement $0 \%$ & $\begin{array}{l}I-25 \% \\
26-50 \% \\
5 I-75 \% \\
76-100 \%\end{array}$ & $\begin{array}{l}0 \\
1 \\
2 \\
3\end{array}$ \\
\hline
\end{tabular}


gavage needle. Portal blood samples were collected 30 min after FITC-Dextran injection. The blood specimens were centrifuged at $4^{\circ} \mathrm{C}, 8000 \mathrm{rpm}$ for $7 \mathrm{~min}$. FITCDextran concentration in blood samples were analyzed through a fluorometer (EnSpire, PerkinElmer, Waltham, MA, USA) at an excitation wavelength of $480 \mathrm{~nm}$ and an emission wavelength of $520 \mathrm{~nm}$. A standard curve prepared by dilution of FITC-Dextran with phosphate buffered saline was used to calculate the concentration of FITC-Dextran in plasma samples.

\section{Protein Preparation}

Intestinal tissues were grounded in liquid nitrogen and lysed in $8 \mathrm{M}$ urea, 1\% NP40,1\% sodium deoxycholate supplemented with $5 \mathrm{mM}$ DTT, $2 \mathrm{mM}$ EDTA and protease inhibitor cocktail (Calbiochem, San Diego, CA, USA). The impurities were precipitated by centrifugation $\left(20,000 \mathrm{~g}, 4^{\circ} \mathrm{C}, 10 \mathrm{~min}\right)$. The protein content in the supernatant was detected. The reduced equivalent protein was alkylated and precipitated with acetone. The precipitate was washed twice with acetone, suspended in $0.1 \mathrm{M}$ TEAB, and treated with trypsin (1/25) (Promega, Madison, WI, USA) for $12 \mathrm{~h}$ at $37^{\circ} \mathrm{C}$. The peptide obtained after termination of digestion was washed on a Strata X C18 SPE column (Phenomenex, Torrance, CA, USA) and dried under vacuum.

\section{Quantitative Proteomic Analysis}

The intestinal tissue samples were quickly frozen in liquid nitrogen and stored at $-80^{\circ} \mathrm{C}$. Then all tissues in a group of samples were ground into powder with liquid nitrogen, and each tube was stored at $200-300 \mathrm{mg}$ and at $-80^{\circ} \mathrm{C}$. One tube of sample (about $220 \mathrm{mg}$ ) had $1 \mathrm{~mL}$ of pre-cooled acetone (supplemented with $2 \mathrm{mM}$ EDTA/10mM DTT/1\% protease inhibitor mixture) added, rinsed, precipitated at $-20{ }^{\circ} \mathrm{C}$ for $1 \mathrm{~h}$, centrifuged at $20,000 \mathrm{~g}$ for $10 \mathrm{~min}$ at $4{ }^{\circ} \mathrm{C}$, and the supernatant was discarded. The residual acetone was air-dried at room temperature. $900 \mathrm{ul}$ of lysate $(8 \mathrm{M}$ urea $/ 50 \mathrm{mM}$ Tris $7.0 /$ $1 \% \mathrm{NP} 40 / 1 \% \mathrm{NaDOC} / 2 \mathrm{mM}$ EDTA $/ 5 \mathrm{mM}$ DTT/1\% protease inhibitor mixture) (Calbiochem, San Diego, CA, USA) were added and the sample was sonicated on ice to promote dissolution. Then the specimen was centrifuged and the supernatant was transferred into a new tube. The protein concentration in the supernatant was determined using a 2D Quant kit (GE Healthcare, Piscataway, NJ, USA).

Two $300 \mu \mathrm{g}$ proteins were taken from each sample, and the gap was filled with lysate. Disulfide bonds were reduced by adding a final concentration of $5 \mathrm{mM}$ DTT and reacted at $30^{\circ} \mathrm{C}$ for 30 minutes. After cooling to room temperature, $30 \mathrm{mM}$ IAM were added to block free thiol groups, and the reaction was protected from light at room temperature for $45 \mathrm{~min}$. 10 volumes of $-20{ }^{\circ} \mathrm{C}$ pre-cooled acetone were added to precipitate the protein and put at $-20{ }^{\circ} \mathrm{C}$ overnight. The specimen was centrifuged, the supernatant was discarded. $80 \%$ acetone pre-cooled at $-20{ }^{\circ} \mathrm{C}$ was added, rinsed, and placed at $-20{ }^{\circ} \mathrm{C}$ for $1 \mathrm{~h}$. Then the supernatant was centrifuged and removed. The protein precipitate was left at room temperature for 10 min, and the residual acetone was evaporated.

$300 \mathrm{ul}$ of $0.12 \mathrm{M}$ TEAB were added and the protein was sonicated on ice to promote precipitation. 6ug trypsin were added, and hydrolyzed at $37^{\circ} \mathrm{C}$ overnight. 6ug trypsin were added, and the reaction was stopped by adding $1 \%$ TFA at a final concentration of 1 hour after $37{ }^{\circ} \mathrm{C}$ hydrolysis. $\mathrm{C}_{18}$ SPE cartridge (Phenomenex, Torrance, CA, USA) was used for demineralization and the peptide was eluted with a vacuum concentrator (Labogene, Lynge, Denmark). The peptide was dissolved in an appropriate volume of $0.5 \mathrm{M}$ TEAB, and 50 ug of the peptide were labeled with iTRAQ reagent, and reacted at room temperature for $1 \mathrm{~h}$.

The dried peptides were reconstituted in the liquid phase A solution $\left(100 \% \mathrm{H}_{2} \mathrm{O}, \mathrm{pH} 10.0\right)$, and $25 \mathrm{ug}$ peptides were taken from each of the eight samples and mixed and centrifuged. The supernatant was loaded onto a $\mathrm{C}_{18}$ column and subjected to reverse gradient separation under alkaline conditions using conventional high performance liquid chromatography (HPLC) (Shimadzu, Kyoto, Japan). According to the peak range displayed by the ultraviolet lamp, about 60 components of the eluted peptide were combined into 21 components, and the vacuum concentrator was drained. Each pre-separated component was dissolved in liquid A solution, centrifuged, and the supernatant was transferred to a sample vial. A 1-hour LC/MS analysis was performed on each component using the $\mathrm{LC} /$ MS system, and the sample load was about $1 \mathrm{ug}$.

\section{Western Blot}

Intestinal tissues were obtained at $6 \mathrm{~h}, 12 \mathrm{~h}$ and $24 \mathrm{~h}$ after CLP or Sham operation to detect expressions of Occludin, Zonula occludens-1 (ZO-1), deleted in malignant brain tumors 1 protein (DMBT1), insulin receptor substrate 2 (IRS2), N-myc downregulated gene 1 (NDRG1) and serum amyloid A-1 protein (SAA1). Total proteins were extracted by cleavage in RIPA buffer (Solarbio, Beijing, China) and protease inhibitor cocktail (Beyotime, Shanghai, China). The homogenates were centrifuged at 
20,000g for $20 \mathrm{~min}$ at $4{ }^{\circ} \mathrm{C}$. And the supernatants were collected as protein samples. The protein concentrations were measured by BCA protein assay kit (Well-bio, Shanghai, China). The samples (50 $\mu \mathrm{g} / \mathrm{sample})$ were solubilized with $5 \times$ SLB (Solarbio, Beijing, China), heated at $100{ }^{\circ} \mathrm{C}$ for $15 \mathrm{~min}$ and then separated by sodium dodecyl sulfate-polyacrylamide gel electrophoresis (SDS-PADE), electrotransferred onto polyvinylidene fluoride membranes (Millipore, Germany), soaked in 5\% nonfat milk in TBST for $2 \mathrm{~h}$ at room temperature, and incubated overnight at $4^{\circ}$ $\mathrm{C}$ with the following primary antibodies against Occludin (1:50,000; Abcam, Cambridge, UK), ZO-1 (1:1000; abcam), DMBT1 (1:500, R\&D, USA), IRS2 (1:1000, CST, USA), NDRG1 (1:1000, CST), SAA1 (1:1000, R\&D) and $\beta$-actin (1:6000, Proteintech, USA). After five washes with TBST, membranes were bound to TBSTdiluted goat antirabbit or antimouse secondary antibodies (1:5000, KPL, USA) for 60min under room temperature. The membrane was soaked in electrochemiluminescence (ECL) reagent. The protein bands were quantified using ImageJ software. The relative levels of Occludin and ZO-1 were standardized to $\beta$-actin. The test was repeated 6 times.

\section{Statistical Analysis}

This study used SPSS 21.0 software. The survival rates were calculated by Fisher exact probability method and expressed as percentages. Quantifiable data were expressed as mean \pm standard deviation (SD). One-way ANOVA was applied for comparison between groups, and Tukey's multiple comparison test was employed to analyze comparison between groups. $P<0.05$ was recognized as statistically significant.

\section{Results}

\section{Survival Rates}

After CLP or Sham procedure, we observed several representative physiological and pathological changes of mice, such as hair characteristics (messy hair), stool characteristics (loose stools), activity frequency (decreased frequency), and respiratory frequency (frequency increase). In the indicator of 7-day survival rates, all mice survived in Sham and Sham $+\mathrm{H}_{2}$ groups, while the survival rates of the mice in Sepsis and Sepsis $+\mathrm{H}_{2}$ groups reduced significantly $(P<0.05)$. However, compared with the mice in Sepsis group, the survival rates of the mice in Sepsis $+\mathrm{H}_{2}$ group that inhaled $2 \% \mathrm{H}_{2}$ were significantly improved (30\% vs $60 \%, P<0.05)$ (Figure 1 ).

\section{Bacterial Load Quantification in Blood, Peritoneal Lavage}

$24 \mathrm{~h}$ after surgery, blood and peritoneal lavage fluid from mice were collected to detect CFU. Compared with Shamoperated mice, the bacterial load of blood and peritoneal lavage fluid in septic mice drastically increased $(P<0.05)$, while the same indicator in septic mice after $\mathrm{H}_{2}$ treatment was significantly reduced $(P<0.05)$ (Figure 2$)$.

\section{Intestinal Histopathological Changes}

To verify the results of intestinal histopathological changes, we performed HE staining. The intestinal villi structure of mice in Sham and Sham $+\mathrm{H}_{2}$ groups was normal and arranged regularly without hyperemia and rupture. In Sepsis group, the intestinal villi were disordered and continuously ruptured, and the submucosa and primary blood vessels were congested. Compared with the Sepsis group, the arrangement of intestinal villi in $\mathrm{H}_{2}$ treated septic mice was slightly irregular, the continuity of intestinal villi was still intact, and the pathological changes of intestinal tissues were significantly improved. According to the small intestinal histological score scale, Sepsis $+\mathrm{H}_{2}$ group were significantly reduced compared with Sepsis group $(P<0.05)$ (Figure 3$)$.

\section{Intestinal Tight Junction Barrier}

As illustrated in Figure 4, compared to the sham operation group, the intestinal permeability of $4.4 \mathrm{kDa}$ FITC-dextran of mice in the Sepsis and Sepsis $+\mathrm{H}_{2}$ groups at $90 \mathrm{~min}$, $180 \mathrm{~min}, 360 \mathrm{~min}$, and $720 \mathrm{~min}$ significantly increased $(P<0.05)$. Compared with the Sepsis group, the intestinal permeability of $4.4 \mathrm{kDa}$ FITC-dextran of mice in Sepsis +

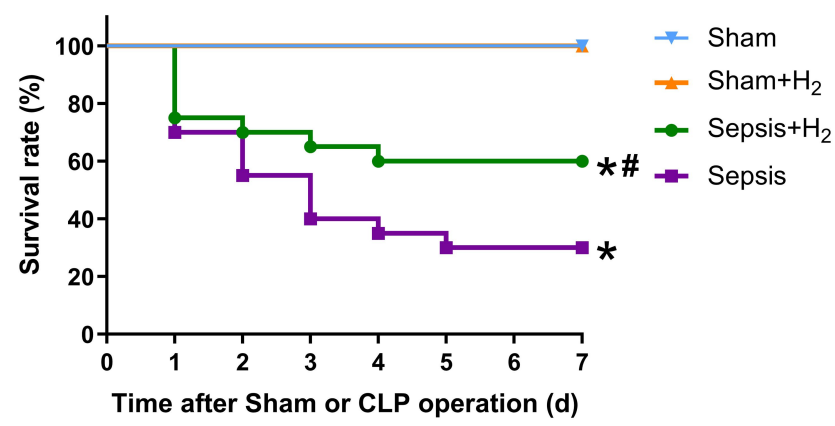

Figure $\mathrm{I} \mathrm{H}_{2}$ inhalation meliorated the 7-day survival rates in septic mice. The survival rates of mice were monitored for 7 days $(n=20)$. $* P<0.05$ versus Sham group, ${ }^{\#} P<0.05$ versus Sepsis group. 
A

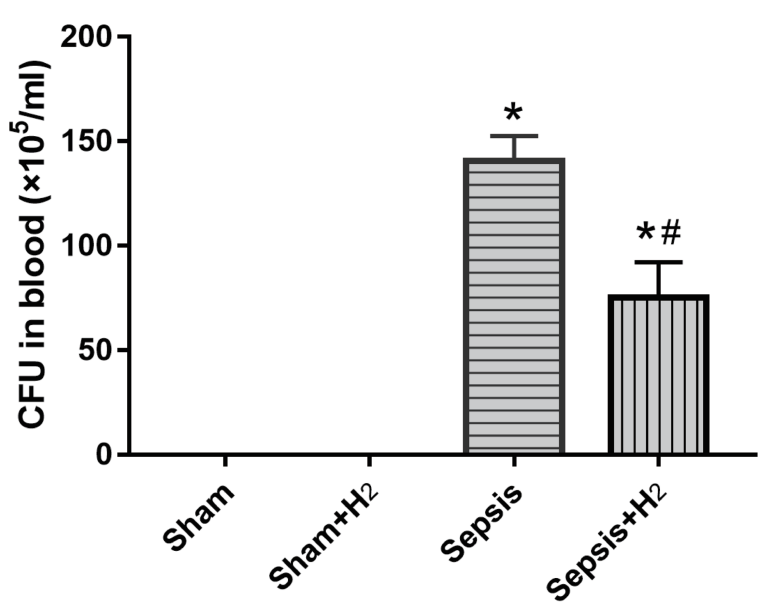

B

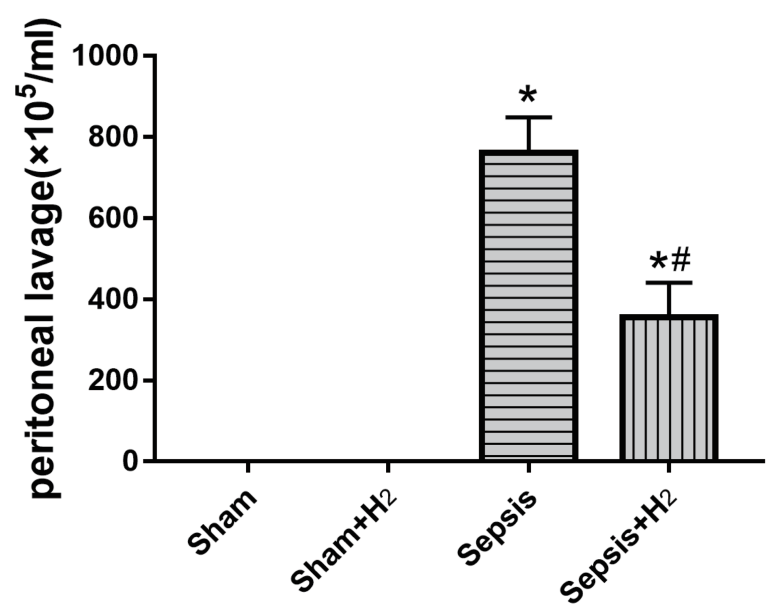

Figure $2 \mathrm{H}_{2}$ enhanced the clearance of bacterial burden in the blood and peritoneal lavage of septic mice. The blood (A) and peritoneal lavage (B) were harvested at 24 $\mathrm{h}$ after Sham or CLP operation. Results were displayed as mean \pm SD $(n=6)$. ${ }^{*} P<0.05$ versus Sham group, ${ }^{\#} P<0.05$ versus Sepsis group.

$\mathrm{H}_{2}$ group was significantly reduced $(P<0.05) . \mathrm{H}_{2}$ can significantly improve the intestinal tight junction barrier in sepsis mice.

\section{Tight Junction Protein Occludin and ZO-I}

Previous studies have shown that the permeability of the intestinal barrier is related to changes in tight junction proteins. ${ }^{14}$ Therefore, we compared the changes of the tight junction proteins Occludin and $\mathrm{ZO}-1$. Intestinal specimens were collected at $6 \mathrm{~h}, 12 \mathrm{~h}$, and $24 \mathrm{~h}$ after Sham or CLP surgery. Quantitative Western blot revealed that the expression levels of Occludin and ZO-1 at three time points in sepsis mice were significantly lower than those of mice after sham surgery $(P<0.05)$. Compared with the mice in the Sepsis group, the levels of Occludin and ZO-1

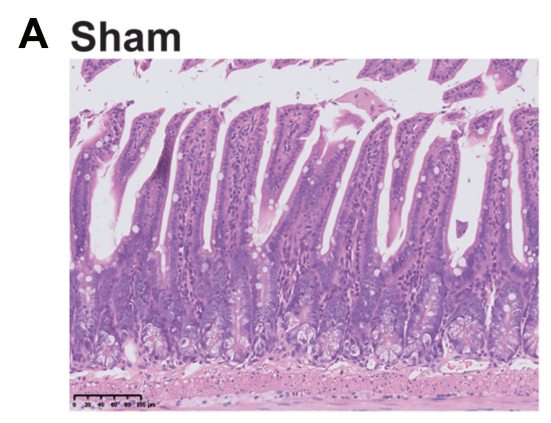

C Sepsis

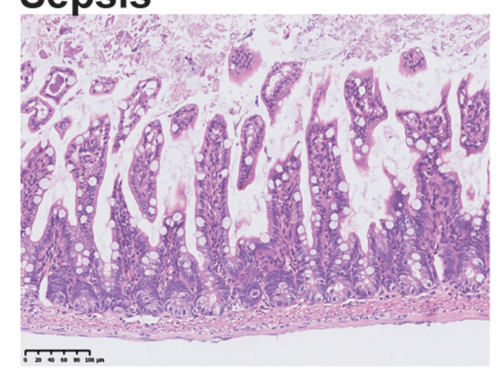

B Sham $+\mathrm{H}_{2}$

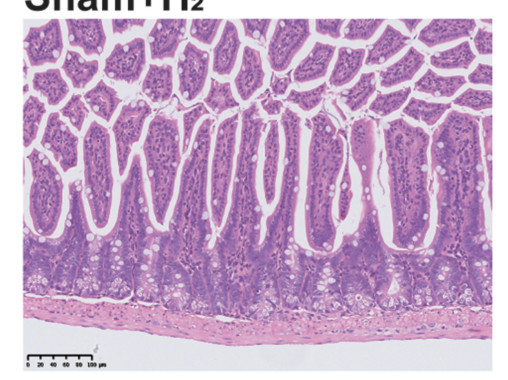

D Sepsis $+\mathrm{H}_{2}$

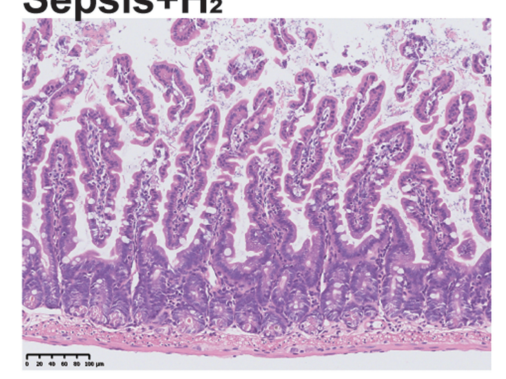

$E$

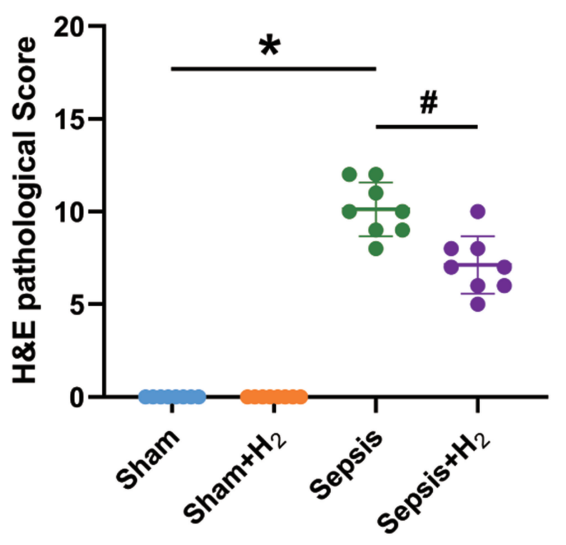

Figure $3 \mathrm{H}_{2}$ can alleviate intestinal pathological damage caused by sepsis. Intestinal tissues were obtained at $24 \mathrm{~h}$ after sham or CLP operation. The structures of intestinal villi were normal in Sham (A) and Sham $\mathrm{H}_{2}$ (B) group. Intestinal villi were disordered, submucosal and primary blood vessels were congested, and the continuity of intestinal villi was broken in Sepsis (C) group. The small intestine histology change in Sepsis $+\mathrm{H}_{2}$ (D) group were significantly improved compared with Sepsis group. (E) HE histopathological scores for each group. Results were displayed as mean \pm SD $(n=6)$. Scale bar $=100 \mu m$. $* P<0.05$ versus Sham group, ${ }^{\#} P<0.05$ versus Sepsis group. 


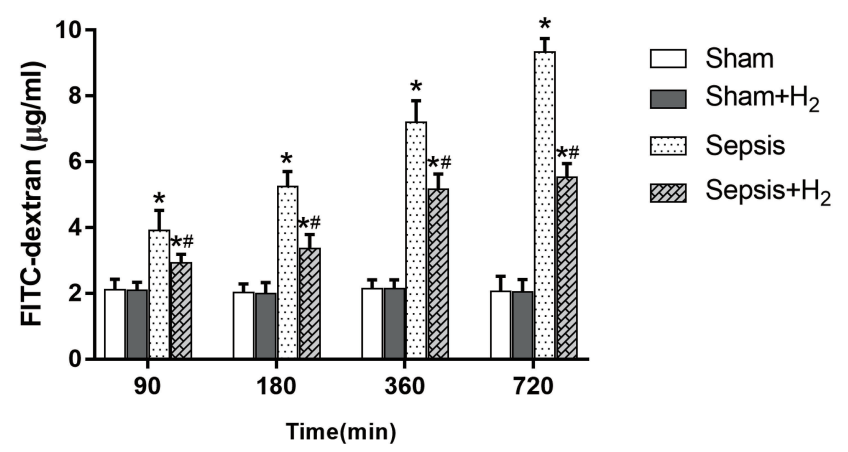

Figure $4 \mathrm{H}_{2}$ can improve the intestinal tight junction barrier. FITC-dextran permeability was measured at $90 \mathrm{~min}, 180 \mathrm{~min}, 360 \mathrm{~min}$, and $720 \mathrm{~min}$ after sham or CLP operation. Results were displayed as mean $\pm S D(n=6)$. $* P<0.05$ versus Sham group, ${ }^{\#} P<0.05$ versus Sepsis group.

at three time points of mice in the Sepsis $+\mathrm{H}_{2}$ group dramatically increased $(P<0.05)$ (Figure 5).

\section{Quantitative Proteomic Analysis}

Intestinal tissue of mice was collected 24 hours after CLP or sham surgery for proteomic analysis, and the differentially expressed proteins were revealed through a highthroughput quantitative proteomics workflow based on iTRAQ. Finally, 5321 proteins were screened out, of which 4194 proteins were quantifiable (fold change $>1.3$ or fold change $<0.77$, coefficient of variance $<30 \%$ ).

Based on a pairwise comparison of the four groups, differential proteins related to $\mathrm{H}_{2}$ can alleviate sepsisassociated intestinal damage and should meet at least one of the following two conditions. Condition 1) induced sepsis caused expressions' differences of some proteins (differential proteins in Sepsis/Sham), and $\mathrm{H}_{2}$ treatment under conditions that had induced sepsis also caused expressions' differences of some proteins (different proteins in Sepsis $\left.+\mathrm{H}_{2} / \mathrm{Sepsis}\right)$. If the up-and-down trend of differential proteins was opposite in the comparison between the two groups, it meant that $\mathrm{H}_{2}$ treatment can reduce or eliminate the difference in protein expressions caused by sepsis, thereby alleviating the symptoms of sepsis. Condition 2) induced sepsis caused differences in the expressions of some proteins (differential proteins in Sepsis/Sham), while sepsis did not cause these proteins to produce differential expressions (non-differential proteins in Sepsis $+\mathrm{H}_{2} / \mathrm{Sham}+\mathrm{H}_{2}$ ) under conditions of $\mathrm{H}_{2}$ treatment. If the differential proteins in the former were not different or opposite in the latter (or the differential proteins in the latter were not different or opposite in the former), it also indicated that these proteins were targets for hydrogen therapy. According to the two conditions, all 22 proteins were screened out under Condition 1 (List 10 of 22 proteins in Table 2), and 193 proteins were identified under Condition 2 (List 10 of 193 proteins in Table 3). Among them, Condition 2 contains most of the proteins of Group 1 (16 proteins), so 199 differential proteins were screened out, which were recognized to be extremely associated with the hydrogen treatment mechanism (or target) for reducing intestinal damage in sepsis mice.

\section{Functional Enrichment Analysis of Differential Proteins}

In aims of further studying the function of $\mathrm{H}_{2}$-related proteins, we conducted gene ontology (GO) on $199 \mathrm{H}_{2}$-related proteins. The GO database (http://www.geneontology.org/) was used to find differential proteins, and the number of differential proteins and background proteins were compared to obtain enrichment significance ( $p$-value) and enrichment fold changes. The smaller the p-value is, the higher the fold change is, and the higher the degree of enrichment of such differential proteins is. We used categories with $\mathrm{p}$-values less than 0.05 and categories with differential proteins greater than 1 as significant enrichments, describing the molecular function of the gene, the cell location where the gene is located, and the biological process involved.

For molecular function, the top three terms in percentage were binding (58\%), catalytic activity (24\%) and molecular transducer activity (6\%). Figure 6A showed six significantly enriched molecular functional GO terms, in addition to the three above, including transporter activity, enzyme regulator activity and molecular function regulator.

For the percentage of GO terms for cell component, we found that cell part $(26 \%)$, organelle $(21 \%)$, and organelle part $(14 \%)$ were the top three terms. Figure 6B showed the 10 significantly enriched GO terms, which were: membrane, extracellular matrix, organelle part, organelle, membrane part, cell part, extracellular region part, macromolecular complex, membrane-enclosed lumen and cell junction.

In regard to biological process GO terminology, singleorganism process $(21 \%)$, cellular process $(19 \%)$, and biological regulation $(13 \%)$ were listed in the top three of the percentages. Figure $6 \mathrm{C}$ showed 14 significantly enriched biological process terms in sequence, namely singleorganism process, cellular process, biological regulation, metabolic process, response to stimulus, developmental process, cellular component organization or biogenesis, 
A

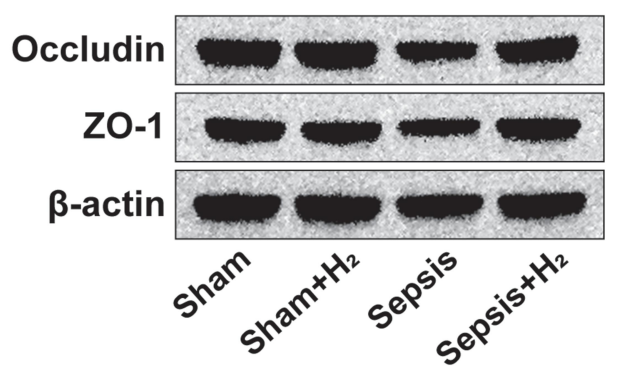

D

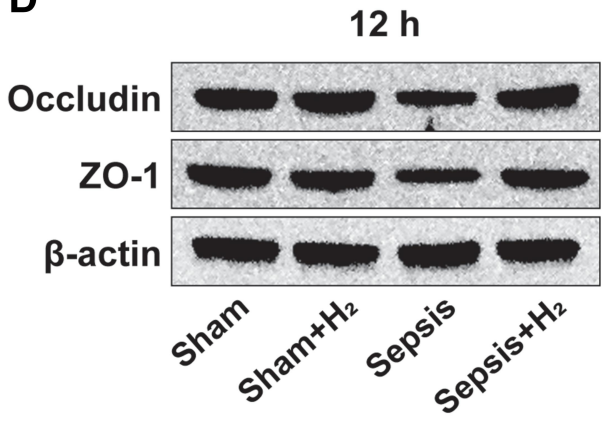

G

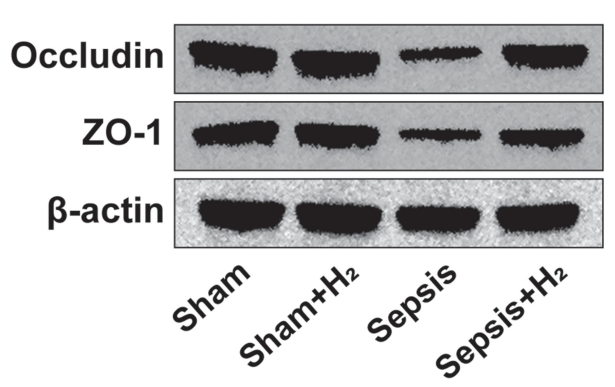

B

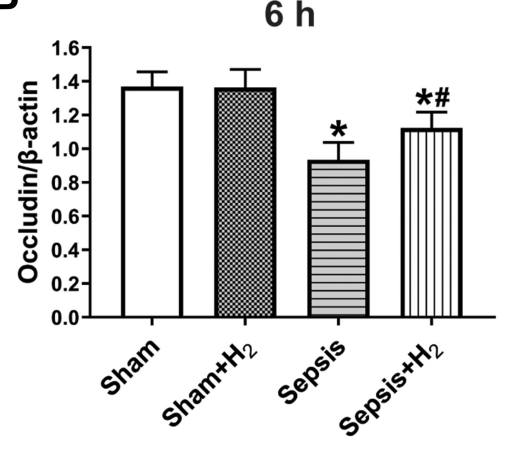

E

$12 \mathrm{~h}$

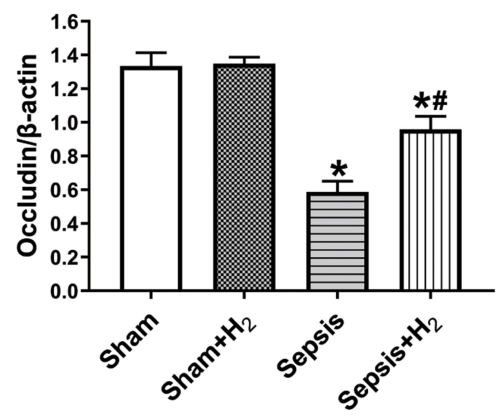

H

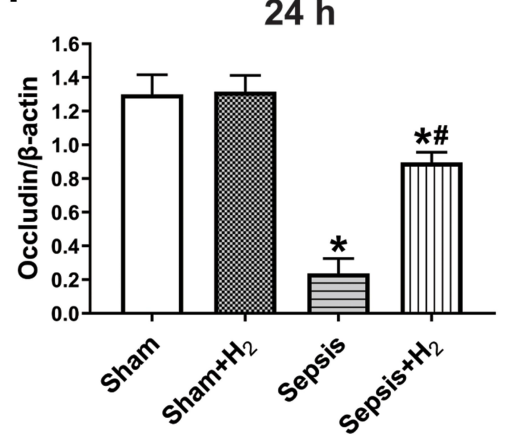

C

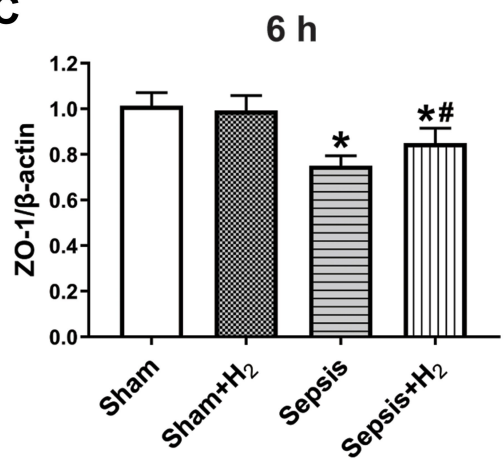

$\mathbf{F}$

$12 \mathrm{~h}$

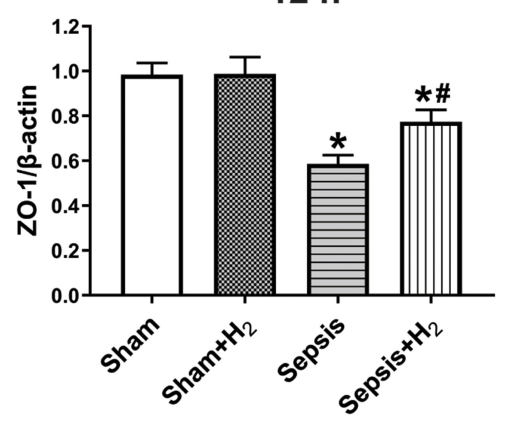

I

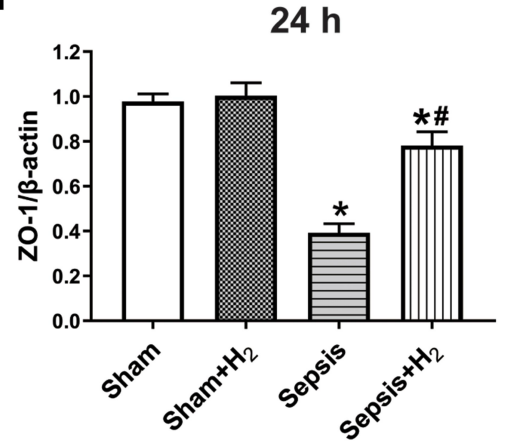

Figure $5 \mathrm{H}_{2}$ can increase the expressions of Occludin and ZO-I. The intestinal tissues were obtained from mice at $6 \mathrm{~h}, 12 \mathrm{~h}$, and $24 \mathrm{~h}$ after sham or CLP operation. The tight junction protein expressions of Occludin and ZO-I measured by Western blot (A, D, G). Quantitative analysis of Occludin (B, E, H) and ZO-I (C, F, I) is shown as the ratio of band density to that of $\beta$-actin respectively. Results were displayed as mean \pm SD $(n=6)$. $* P<0.05$ versus Sham group, ${ }^{\#} P<0.05$ versus Sepsis group.

multicellular organismal process, immune system process, multi-organism process, rhythmic process, localization, reproductive process, behavior, and locomotion.

We then explored the Kyoto Encyclopedia of Genes and Genomes (KEGG) function of 199 different proteins through the KEGG database (http://www.kegg.jp/kegg/ pathway.html). Figure 6D showed the top ten significantly enriched signaling pathways in order: vitamin digestion and absorption, protein digestion and absorption, fat digestion and absorption, linoleic acid metabolism, nitrogen metabolism, pancreatic secretion, thyroid hormone synthesis, retinol metabolism, ECM-receptor interaction, and arachidonic acid metabolism.
We also conducted a functional interaction network analysis based on the STRING database (www.string-db. org). In the association network, there were four significantly enriched interaction clusters: ribosomal protein, trypsin-related protein, heat shock protein and protein disulfide isomerase, and collagen (Figure 7).

\section{Verification of $\mathrm{H}_{2}$-Related Differential Protein}

To verify the proteomics results, we used quantitative Western blot for further testing. Based on a comprehensive analysis of protein function and the feasibility of commercial antibody application, proteins of 
Table 2 List of the Several $\mathrm{H}_{2}$-Related Significantly Differential Proteins According With Condition One

\begin{tabular}{|c|c|c|c|c|}
\hline Protein Name & $\begin{array}{l}\text { Protein } \\
\text { IDs }\end{array}$ & $\begin{array}{l}\text { Gene } \\
\text { Name }\end{array}$ & $\begin{array}{l}\text { Sepsis/ } \\
\text { Sham }\end{array}$ & $\begin{array}{l}\text { Sepsis }+\mathrm{H}_{2} / \\
\text { Sepsis }\end{array}$ \\
\hline $\begin{array}{l}\text { Hemoglobin } \\
\text { subunit beta-2 }\end{array}$ & P02089 & Hbb-b2 & 1.5165 & 0.5305 \\
\hline $\begin{array}{l}\text { Deleted in } \\
\text { malignant brain } \\
\text { tumors I protein }\end{array}$ & Q60997 & Dmbtl & 1.679 & 0.675 \\
\hline Protein NDRGI & Q62433 & Ndrgl & 1.701 & $0.7 \mathrm{I}$ \\
\hline $\begin{array}{l}\text { Fatty acid-binding } \\
\text { protein, adipocyte }\end{array}$ & P04II7 & Fabp4 & 1.3825 & 0.7285 \\
\hline $\begin{array}{l}\text { Cytochrome } \\
\text { P450 3A13 }\end{array}$ & Q64464 & Сур3а। 3 & 2.4345 & 0.6635 \\
\hline Gastrotropin & P5II62 & Fabp6 & 0.402 & 5.913 \\
\hline Galectin-6 & O5489I & Lgals6 & 0.2315 & 1.701 \\
\hline $\begin{array}{l}\text { Acyl-coenzyme } \\
\text { A thioesterase 2, } \\
\text { mitochondrial }\end{array}$ & Q9QYR9 & $A \cot 2$ & 1.3355 & 0.756 \\
\hline $\begin{array}{l}\text { Regenerating } \\
\text { islet-derived } \\
\text { protein 3-beta }\end{array}$ & P35230 & Reg3b & 11.5745 & 0.506 \\
\hline $\begin{array}{l}\text { Serum amyloid } \\
\text { A-I protein }\end{array}$ & P05366 & Saal & 3.2255 & 0.556 \\
\hline
\end{tabular}

DMBT1, IRS2, NDRG1 and SAA1 were picked out for further experiment. Figure 8 demonstrated the expressions and ratios of four measured proteins. Comparing to the Sham group, the levels of DMBT1, IRS2, NDRG1 and SAA1 in mice of Sepsis group significantly increased $(P<$ 0.05). Compared with the Sepsis group, the levels of DMBT1, IRS2, NDRG1 and SAA1 of mice in the Sepsis + $\mathrm{H}_{2}$ group were remarkably reduced $(P<0.05)$.

\section{Discussion}

Sepsis is becoming more and more common clinically and has quite high mortality. It has been a major complication of severe trauma, burns, shock and major surgery, and has become one of the major causes of death in critical illness. ${ }^{15-17}$ Sepsis and multiple organ failure associated with sepsis remain major challenges for scientists and clinicians. For clinical sepsis, CLP in rats or mice is commonly applied to simulate clinical appendicitis perforation or diverticulitis perforation, which was considered as the gold standard for the animal model of sepsis. ${ }^{18}$ In
Table 3 List of the Several $\mathrm{H}_{2}$-Related Significantly Differential Proteins According With Condition Two

\begin{tabular}{|l|l|l|l|l|}
\hline Protein Name & $\begin{array}{l}\text { Protein } \\
\text { IDs }\end{array}$ & $\begin{array}{l}\text { Gene } \\
\text { Name }\end{array}$ & $\begin{array}{l}\text { Sepsis/ } \\
\text { Sham }\end{array}$ & $\begin{array}{l}\text { Sepsis+H } \\
\text { ISham+H }\end{array}$ \\
\hline $\begin{array}{l}\text { Synapse-associated } \\
\text { protein I }\end{array}$ & Q9D5V6 & SyapI & 2.4945 & 0.817 \\
\hline Lithostathine-2 & Q0873I & Reg2 & 2.0655 & 1.2855 \\
\hline $\begin{array}{l}\text { Sodium/nucleoside } \\
\text { cotransporter 2 }\end{array}$ & O88627 & Slc28a2 & 2.009 & 1.2005 \\
\hline $\begin{array}{l}\text { CCAAT/enhancer- } \\
\text { binding protein } \\
\text { beta }\end{array}$ & P28033 & Cebpb & 1.8885 & 1.216 \\
\hline Protein DPCD & Q8BPA8 & Dpcd & 1.8235 & 1.0625 \\
\hline $\begin{array}{l}\text { Alpha- } \\
\text { 2-antiplasmin }\end{array}$ & Q61247 & Serpinf2 & 1.8155 & 0.9275 \\
\hline $\begin{array}{l}\text { Ribosome } \\
\text { biogenesis protein } \\
\text { BOPI }\end{array}$ & P97452 & BopI & 1.7595 & 1.204 \\
\hline $\begin{array}{l}\text { Insulin receptor } \\
\text { substrate 2 }\end{array}$ & P8II22 & Irs2 & 1.7455 & 1.0835 \\
\hline Protein NDRGI & Q62433 & NdrgI & 1.701 & 1.145 \\
\hline $\begin{array}{l}\text { Placenta-specific } \\
\text { gene 8 protein }\end{array}$ & Q9J148 & Plac8 & 1.6695 & 1.222 \\
\hline
\end{tabular}

this study, a sepsis model was prepared using CLP. The results showed that the bacterial load of blood samples and peritoneal lavage fluid in mice in CLP group increased, which proved that the mouse CLP sepsis model was successfully prepared. After successful preparation of the mouse sepsis model, the histopathological analysis of the intestinal tissue was performed. The results showed that the intestinal villus was disordered, the submucosal and primary vascular congestion, and the intestinal villi were continuously broken. The model of mouse sepsis intestinal injury was proved to be successful.

Since Ohsawa et al first reported that hydrogen activity can be used as a hydroxyl radical scavenger, ${ }^{19}$ it has been widely demonstrated that hydrogen also has antiinflammatory, anti-apoptotic, and cytoprotective effects. ${ }^{20}$ At present, it is widely believed that both $\mathrm{H}_{2}$ and hydrogenrich saline have good therapeutic effects on sepsis. Our previous research have shown that hydrogen therapy had beneficial effects on sepsis and sepsis-associated organ dysfunction, involving the brains, lungs, and intestines ${ }^{7-9}$ We also confirmed that $2 \% \mathrm{H}_{2}$ inhalation dramatically 
A

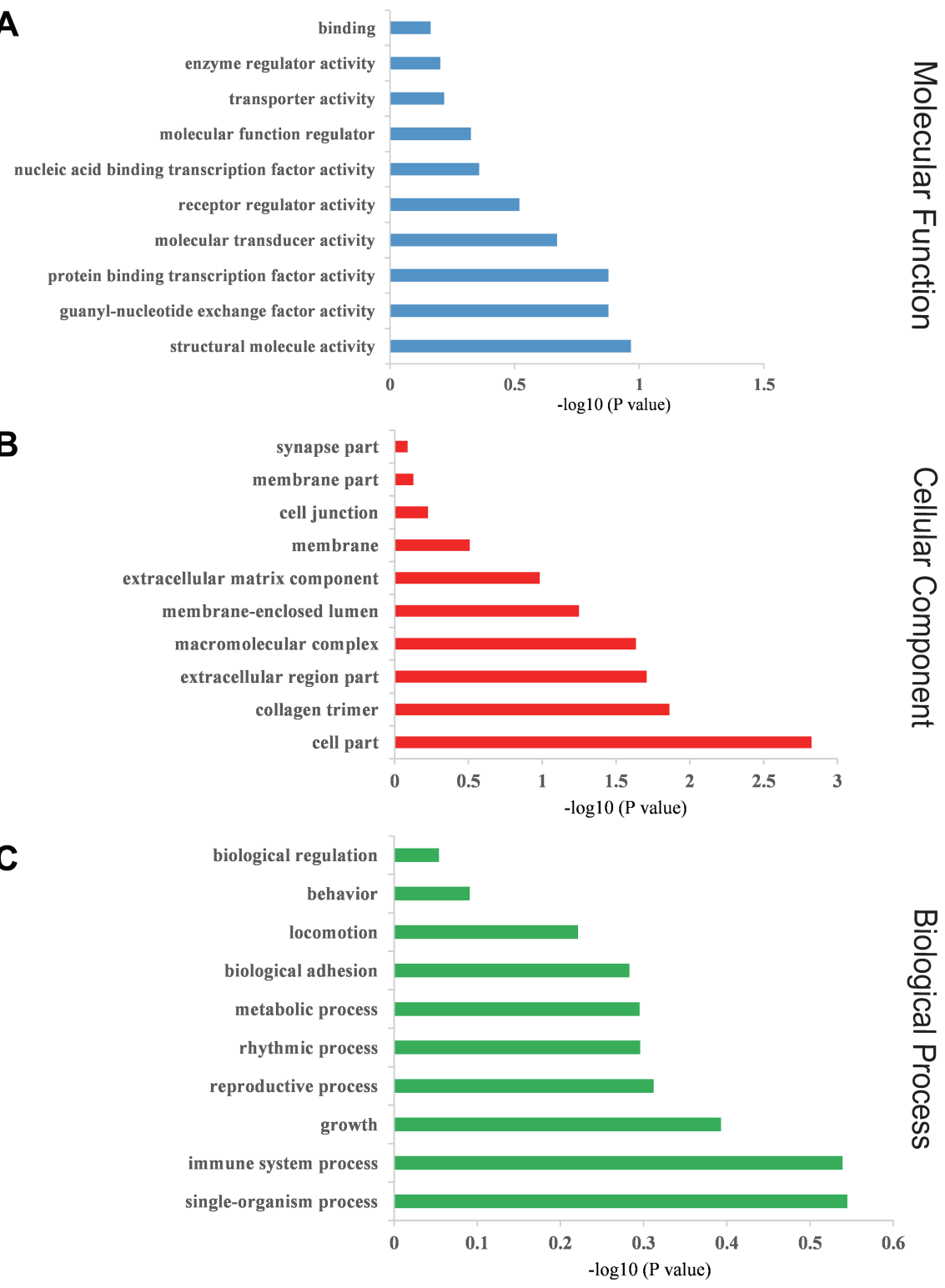

D

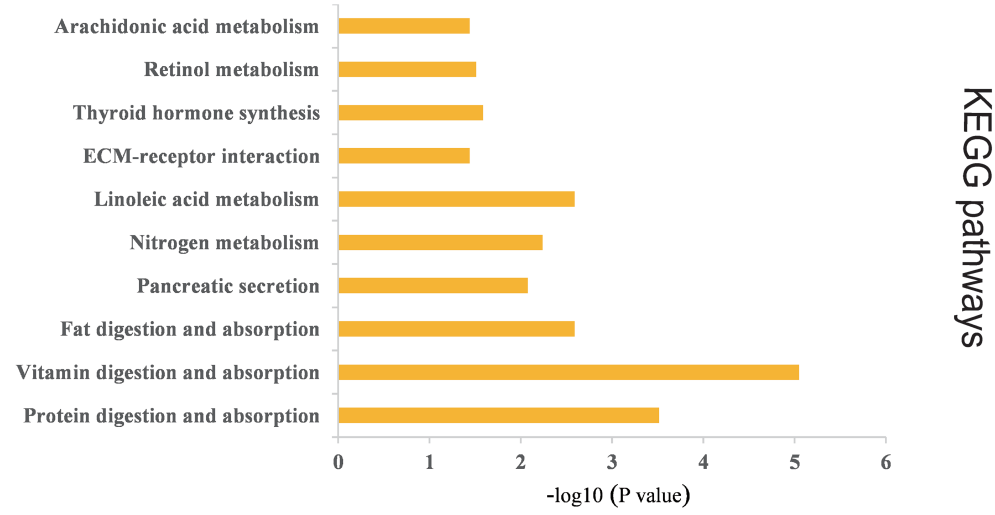

Figure 6 Significant enrichment analysis of differentially expressed proteins. We performed GO and KEGG to further understand the functions of $49 \mathrm{H}_{2}$-related proteins. (A) The top ten significantly enriched molecular function GO terms. (B) The top ten significantly enriched cellular component GO terms. (C) The top ten significantly enriched biological process GO terms. (D) Differential protein enriched KEGG pathway $(n=10)$. 


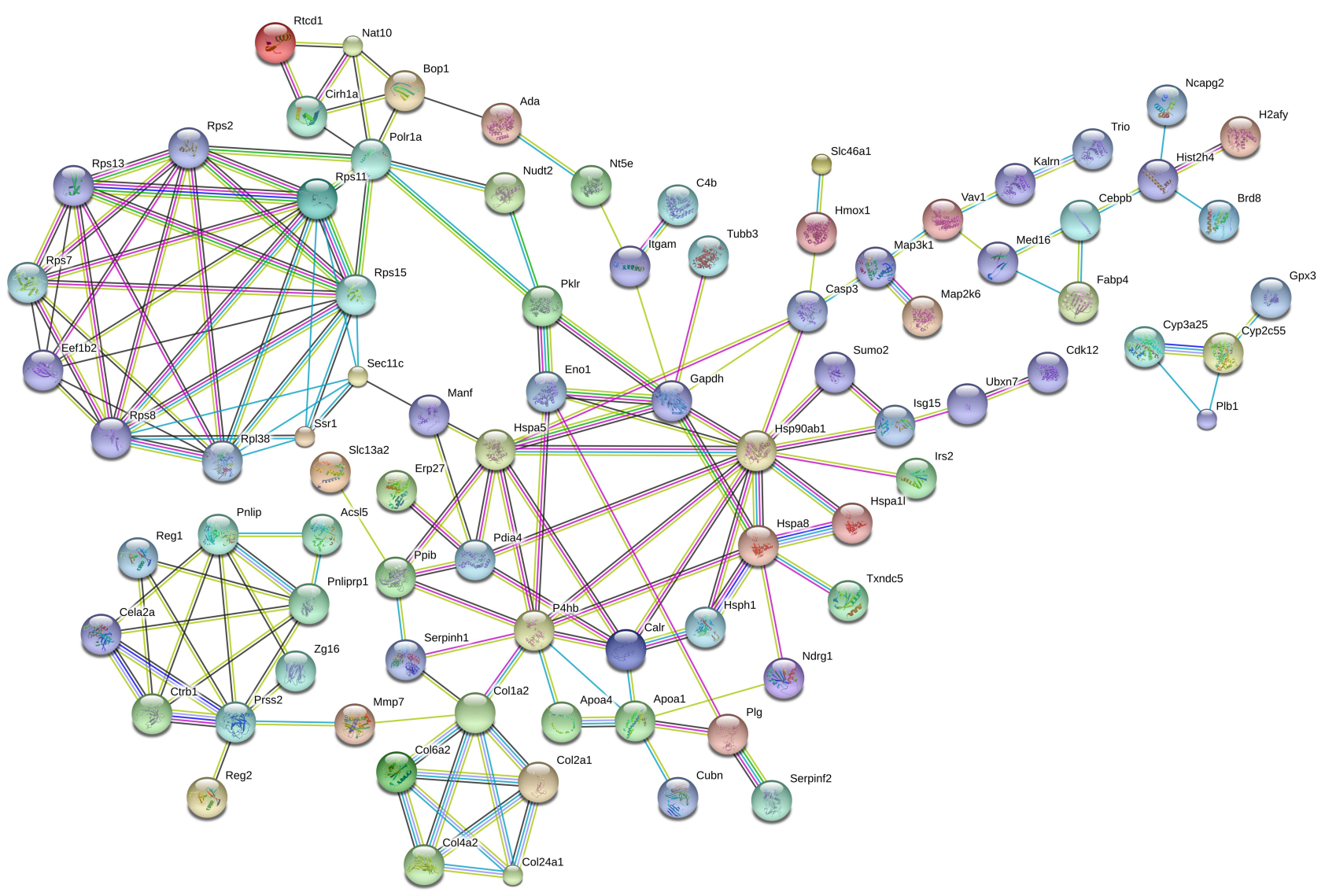

Figure 7 Interconnected protein networks composed of differential proteins.

meliorated the survival rate of septic mice in a concentration- and time-dependent manner, and the therapeutic scheme that $2 \% \mathrm{H}_{2}$ inhalation beginning at both $1 \mathrm{st}$ and 6 th hour after sham or CLP operation was the safest and the most economical and effective scheme of hydrogen treatment. ${ }^{7}$ In this study, the mice were inhaled $2 \% \mathrm{H}_{2}$ for 1 $h$ at 1 st and 6 th hour after CLP and sham surgery. And the results confirmed that $\mathrm{H}_{2}$ inhalation could effectively improve the 7-day survival rates of sepsis mice. The gut is the target organ for critical diseases, including trauma, burns, ischemia-reperfusion injury, and sepsis. ${ }^{21}$ Studies have confirmed that hydrogen-rich saline can regulate intestinal barrier dysfunction and bacterial migration in mouse models of sepsis. ${ }^{22}$ Previous studies have shown that the loss of barrier function of intestinal epithelial cells may be caused by the destruction of epithelial cells and severe metabolic injury caused by sepsis. ${ }^{23}$ These effects may be related to the disturbance of intestinal microbiota after sepsis. In order to prevent the displacement of intestinal endogenous bacteria, it is considered to involve four defense mechanisms: mechanical barrier, immune barrier, biological barrier and chemical barrier, among which mechanical barrier is the most important, and the connection between intestinal epithelial cells and adjacent cells is the determinant of mechanical barrier. ${ }^{24}$ The connections between intestinal epithelial cells are most important for tight connections, especially in maintaining intestinal barrier permeability. Tight junctions are mainly composed of tight junction proteins, including occludin, zonal closure protein $(\mathrm{ZO})$ family, claudin protein family and junction adhesion molecule (JAM), etc. However, the degree of sealing varies according to external stimuli and pathological conditions. ${ }^{25,26}$ Studies have confirmed that inflammatory response, stress response and ischemia-hypoxia reperfusion injury are closely related to intestinal barrier dysfunction. The outcomes of this research illustrated that the permeability of the intestinal tract to $4.4 \mathrm{kDa}$ FITC-dextran was notably enhanced in Sepsis group and Sepsis $+\mathrm{H}_{2}$ group at $90 \mathrm{~min}, 180 \mathrm{~min}, 360 \mathrm{~min}$ and $720 \mathrm{~min}$ after sepsis surgery compared with the Sham group. After inhalation of $\mathrm{H}_{2}$ for $60 \mathrm{~min}$ at $1 \mathrm{st} \mathrm{h}$ and 6 th hour after CLP operation, the permeability of the $4.4 \mathrm{kDa}$ FITC-dextran was drastically 


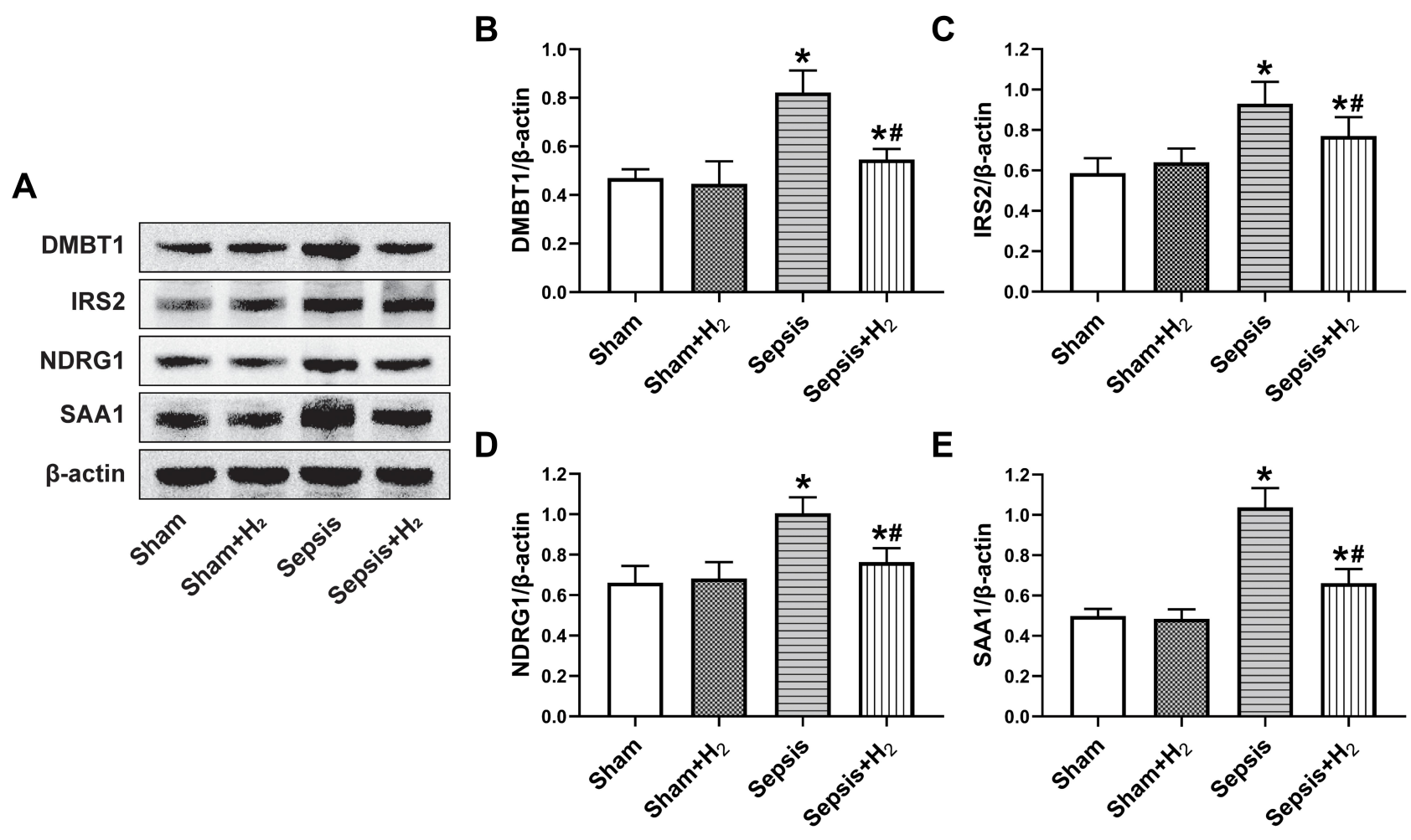

Figure 8 Effects of $\mathrm{H}_{2}$ on the protein expressions of DMBTI, IRS2, NDRGI, and SAAI in intestinal tissue of septic mice. The intestinal samples were harvested at 24 h after sham or CLP operation. The protein expressions of DMBTI, IRS2, NDRGI, and SAAI measured by Western blot (A). Quantitative analysis of DMBTI (B), IRS2 (C), NDRGI (D), and SAAI (E) is shown as the ratio of band density to that of $\beta$-actin respectively. Results were displayed as mean \pm SD ( $n=6$ ). $* P<0.05$ versus Sham group, ${ }^{\#} P<0.05$ versus Sepsis group.

decreased in the Sepsis $+\mathrm{H}_{2}$ group compared with the Sepsis group. Compared with the Sepsis group, the expressions of tight junction proteins Occludin and ZO-1 were upregulated in the Sepsis $+\mathrm{H}_{2}$ group at $6 \mathrm{~h}, 12 \mathrm{~h}$, and $24 \mathrm{~h}$ after CLP procedure. The experimental results show that hydrogen can improve intestinal barrier dysfunction intestinal mucosal permeability.

Our research group has been committed to the study of multiple organ damage caused by sepsis, including lung, brain, intestine, etc. In our previous studies, iTRAQ-based proteomics technology was used to analyze the effect of $\mathrm{H}_{2}$ on sepsis induced lung injury and sepsis-associated encephalopathy. ${ }^{12,27}$ In this study, we found that hydrogen can play a protective role in intestinal barrier function caused by sepsis, but the specific mechanism is still unclear. Quantitative proteomics techniques were applied, including in vitro iTRAQ labeling in combination with LC-MS/MS. All 199 proteins were screened out and believed to be extremely related to the mechanism by which hydrogen improves intestinal barrier function in septic mice. The functions and pathways of 199 proteins were annotated by GO, KEGG database, and STRING protein interaction network.
$\mathrm{GO}$ analysis revealed that the $\mathrm{H}_{2}$-related differential proteins primarily included the molecular function (immune system process, multicellular system process, cellular component organization or biogenesis, developmental process, etc.), and the cellular location part (macromolecular complex, extracellular region part, organelle part, cell part, etc.), and biochemical process (transporter activity, catalytic activity, binding, etc.). Severe sepsis remains a clinical and biological challenge. The immune system has been shown to be the treatment target for sepsis. Figuring out how immune response modulators alter sepsis is necessary and provides reliable information for treatment. ${ }^{28}$ Studies have shown that recombinant IL-7 and PD1-specific antibodies can reverse the underlying immune deficiency in sepsis, thereby increasing the survival rates of many clinically relevant sepsis animal models. ${ }^{29}$ The intestine has been considered the initiator of sepsis and multiple organ dysfunction syndrome for decades. Studies have found that a balanced microbiota is essential for maintaining intestinal and systemic immune homeostasis, and disrupting the integrity of the gut microbiota may increase susceptibility to sepsis. ${ }^{30}$ In 
the present study, significantly enriched molecular functions include system process, cell localization and biochemical processes including macromolecular complex, extracellular region part, transporter activity, and catalytic activity, suggesting that $\mathrm{H}_{2}$ may through immune system regulation and intestinal cell repair alleviate sepsis induced intestinal injury, thereby reducing intestinal inflammation and cell tight junction destruction, and improving immune function in septic mice, improving intestinal barrier function.

In our KEGG pathway analysis, $\mathrm{H}_{2}$-related differential proteins were notably enriched in thyroid hormone synthesis signaling pathways, nitrogen metabolism signaling pathways, digestion and absorption signaling pathways (vitamins, proteins and fats). Studies have found that sepsis can lead to thyroid injury and dysfunction, reduce serum thyroid hormone levels, and increase thyroid follicular epithelial cell death. ${ }^{31}$ Other studies have confirmed that pneumococcal-induced sepsis can significantly increase globulin synthesis, reduce albumin synthesis, and enhance nitrogen excretion and metabolism. ${ }^{32}$ In summary, it is suggested that $\mathrm{H}_{2}$ may reduce intestinal injury in septic mice through the effects of thyroid hormone synthesis and nitrogen metabolism signaling pathway.

Four clusters in the STRING protein-protein interaction networks were identified. The first group was mainly ribosomal proteins. Studies have found that sepsis induces protein synthesis in muscle, and the number of ribosomes and translation factor abundance was reduced. ${ }^{33}$ The discovery of ribosomal protein clustering suggests that the positive mechanism of $\mathrm{H}_{2}$ on sepsis may be due to improved expressions of ribosomal proteins to improve protein synthesis. Second, a set of trypsin-related digestive enzyme proteins was found in STRING. Studies have confirmed that in the multiple organ failure of sepsis, digestive enzymes and their degradation products in the intestinal lumen can lead to direct destruction of the intestinal tissue and self-digestion, and may even lead to loss of cell function and systemic inflammatory response. ${ }^{34}$ Another study found that blocking the digestive enzymes in the intestinal cavity in sepsis can reduce the destruction of the mucosal barrier and reduce the occurrence of multiple organ dysfunction. ${ }^{35}$ In summary, it suggests that the therapeutic mechanism of $\mathrm{H}_{2}$ inhalation for intestinal damage caused by sepsis may involve blocking trypsinrelated digestive enzymes. Third, STRING network analysis also discovered heat shock proteins and protein disulfide isomerase-associated proteins. Studies have found that by promoting the expression of heat shock protein 90 (HSP90) can reduce myocardial cell apoptosis in septic rats. ${ }^{36}$ Studies have confirmed that mRNA of heat shock protein 72 (HSP72) in monocytes and lymphocytes is activated and protein expression is enhanced in severe sepsis or SIRS, thereby improving the defense against fever. $^{37}$ In summary, it is shown that the therapeutic mechanism of $\mathrm{H}_{2}$ on intestinal damage in sepsis may involve enhancing the expressions of heat shock proteinrelated proteins. The last group was a collagen-related protein. The study found that the level of cross-linked telopeptides of type I collagen (ICTP) in the serum of patients with severe sepsis was significantly elevated, suggesting that it can be used as a marker of the severity and prognosis of sepsis. ${ }^{38}$ Another study confirmed that enterococcus faecalis can degrade collagen, leading to sepsis caused by intestinal anastomotic leakage. ${ }^{39}$ In summary, it is suggested that the positive mechanism of $\mathrm{H}_{2}$ on intestinal injury of sepsis may be related to the inhibition of collagen degradation. In view of these protein clusters, the positive effect of $\mathrm{H}_{2}$ on sepsis may be related to the synthesis of ribosomal proteins, blocking trypsin, enhancing heat shock protein expression, and inhibiting collagen degradation.

Four differentially expressed proteins (SAA1, NDRG1, DMBT1, IRS2) were picked out for further experiment. The trend of levels of these proteins was verified by Western blot to be very consistent with proteomics data, indicating the accuracy of high-throughput quantitative proteomics analysis based on iTRAQ and LC-MS/MS. But the difference in Western blot measurements is greater than that in protein expressions in proteomics data. This circumstance is in line with the tendency of iTRAQ technology to underrate the change in protein folding, since it contaminates near-isostatic ion co-segregation and fragmentation. ${ }^{40}$ Therefore, low-throughput molecular biology techniques should be applied to detect protein levels.

SAA1 is an acute phase protein that is widely recognized as an accurate and sensitive indicator of inflammation. ${ }^{41}$ In the inflammatory state, serum amyloid A1 can be increased 1000 times in vivo. ${ }^{42}$ Studies have confirmed that SAA1 can be induced by lipopolysaccharide (LPS) and is associated with pathological changes in a variety of diseases, indicating that SAA1 participates in the expressions of inflammatory factors induced by LPS. ${ }^{43}$ It has been found that inhibition of SAA1 can abolish the release of inflammatory factors in vascular smooth muscle 
cells (VSMCs) induced by LPS through mediating the p38MAPK/NF-kB pathway to inhibit NOX/ROS pathway. ${ }^{44}$ The mass spectrometric data indicated that the expression rate of SAA1 in Sepsis/Sham was 3.2255, while the expression rate in Sepsis $+\mathrm{H}_{2} / \mathrm{Sepsis}$ was 0.556 . While $\mathrm{H}_{2}$ treatment notably down-regulated the expression of SAA1, which may be involved in inhibition of the inflammatory response.

NDRG1 is an intracellular protein consisting of 394 amino acids, highly preserved in multicellular organisms, and its expression is induced by stress stimulation. ${ }^{45}$ Studies have confirmed that NDRG1 can reduce the expressions of chemokines inflammatory cells in the regulation of pancreatic cancer, causing a significant reduction in neutrophil recruitment. ${ }^{46}$ Meanwhile, studies have found that NDRG1 plays an key role in the angiogenesis of gastric cancer tumors induced by IL- $1 .^{47}$ The mass spectrometric data demonstrated that the expression rate of NDRG1 in Sepsis/Sham was 1.701, while the expression rate in Sepsis $+\mathrm{H}_{2} /$ Sepsis was 0.71 . While $\mathrm{H}_{2}$ treatment notably down-regulated the expression of NDRG1, which may be associated with inhibited of neutrophil recruitment.

DMBT1 pertained to the superfamily of scavenger receptor cysteine-rich (SRCR) genes. ${ }^{48}$ Studies have shown that DMBT1 is mainly expressed in epithelial cells and secreted by epithelial cells in a polarized manner, for example, to the extracellular matrix (squamous epithelial cells) or to the lumen (monolayer epithelial cells and glands). ${ }^{49}$ Studies have confirmed that DMBT1 can inhibit the cell invasion of Salmonella enterica, inhibit LPSinduced NF- $\mathrm{\kappa B}$ activation and cytokine secretion. ${ }^{50}$ Therefore, DMBT1 may play an important role in the first line of mucosal defense, with anti-inflammatory and bacterial cell wall components immune rejection. The mass spectrometric data illustrated that the expression rate of DMBT1 in Sepsis/Sham was 1.679, while the expression rate in Sepsis $+\mathrm{H}_{2} / \mathrm{Sepsis}$ was 0.675 ; while $\mathrm{H}_{2}$ treatment notably down-regulated the expression of DMBT1, which may be involved in inhibition of inflammatory responses and immune rejection.

IRS2 regulates various cellular processes through insulin. Studies have shown that the expressions of cell signal inhibitors are elevated in insulin-sensitive tissues of patients with endotoxemia, and insulin resistance can be induced by inhibiting IRS2 phosphorylation and its downstream signals. ${ }^{51}$ The mass spectrometric data indicated that the expression rate of IRS2 in Sepsis/Sham was
1.7455, while the expression rate in Sepsis $+\mathrm{H}_{2} /$ Sepsis was 1.0835 . While $\mathrm{H}_{2}$ treatment notably down-regulated the expression of IRS2, which may be involved in insulinmediated cellular processes.

\section{Conclusion}

We used iTRAQ labeling combined with LC-MS/MS quantitative proteomics method to find that 199 differential proteins were related with $\mathrm{H}_{2}$ in the intestinal protection of sepsis. The identified proteins were classified by molecular function, cell localization, and biochemical processes by functional enrichment analysis. $\mathrm{H}_{2}$-related differential proteins were notably enriched in the following signaling pathways, including thyroid hormone synthesis signaling pathway, nitrogen metabolism signaling pathways, digestion and absorption signaling pathways (vitamins, proteins and fats). In addition, $\mathrm{H}_{2}$ reduced intestinal injury in septic mice by down-regulating the expressions of SAA1, NDRG1, DMBT1, and IRS2. The mechanism and clinical application of these differentially rich proteins in intestinal injury caused by sepsis are for further study.

\section{Acknowledgments}

This research was supported by the Chinese National Natural Science Foundation (grant nos. 81671888 and 81772043), the Tianjin Natural Science Foundation (grant nos. 17JCYBJC24800, 18JCZDJC35100 and 18JCQNJC13000).

\section{Disclosure}

The authors report no conflicts of interest in this work.

\section{References}

1. Schorr CA, Zanotti S, Dellinger RP. Severe sepsis and septic shock: management and performance improvement. Virulence. 2014;5 (1):190-199. doi:10.4161/viru.27409

2. Ferlito M, Wang Q, Fulton WB, et al. Hydrogen sulfide [corrected] increases survival during sepsis: protective effect of CHOP inhibition. J Immunol. 2014;192(4):1806-1814. doi:10.4049/jimmunol.1300835

3. Osterbur K, Mann FA, Kuroki K, DeClue A. Multiple organ dysfunction syndrome in humans and animals. $J$ Vet Intern Med. 2014;28 (4):1141-1151. doi:10.1111/jvim.12364

4. Terry S, Nie M, Matter K, Balda MS. Rho signaling and tight junction functions. Physiology (Bethesda). 2010;25(1):16-26.

5. Gong ZY, Yuan ZQ, Dong ZW, Peng YZ. Glutamine with probiotics attenuates intestinal inflammation and oxidative stress in a rat burn injury model through altered iNOS gene aberrant methylation. $\mathrm{Am}$ $J$ Transl Res. 2017;9(5):2535-2547.

6. Huang CS, Kawamura T, Toyoda Y, Nakao A. Recent advances in hydrogen research as a therapeutic medical gas. Free Radic Res. 2010;44(9):971-982. doi:10.3109/10715762.2010.500328 
7. Liu L, Xie K, Chen H, et al. Inhalation of hydrogen gas attenuates brain injury in mice with cecal ligation and puncture via inhibiting neuroinflammation, oxidative stress and neuronal apoptosis. Brain Res. 2014;1589:78-92. doi:10.1016/j.brainres.2014.09.030

8. Yu Y, Yang Y, Bian Y, et al. Hydrogen gas protects against intestinal injury in wild type but not NRF2 knockout mice with severe sepsis by regulating HO-1 and HMGB1 release. Shock. 2017;48 (3):364-370. doi:10.1097/SHK.0000000000000856

9. Yu Y, Yang Y, Yang M, Wang C, Xie K, Yu Y. Hydrogen gas reduces HMGB1 release in lung tissues of septic mice in an $\mathrm{Nrf} 2 /$ HO-1-dependent pathway. Int Immunopharmacol. 2019;69:11-18. doi:10.1016/j.intimp.2019.01.022

10. Yang T, Wang L, Sun R, et al. Hydrogen-rich medium ameliorates lipopolysaccharide-induced barrier dysfunction via Rhoa-Mdia1 signaling in Caco-2 cells. Shock. 2016;45(2):228-237. doi:10.1097/ SHK.0000000000000503

11. Aggarwal S, Yadav AK. Dissecting the iTRAQ data analysis. Methods Mol Biol. 2016;1362:277-291.

12. Bian Y, Qin C, Xin Y, et al. Itraq-based quantitative proteomic analysis of lungs in murine polymicrobial sepsis with hydrogen gas treatment. Shock. 2018;49(2):187-195. doi:10.1097/ SHK.0000000000000927

13. Jin Y, Hofseth AB, Cui X, et al. American ginseng suppresses colitis through p53-mediated apoptosis of inflammatory cells. Cancer Prev Res (Phila). 2010;3(3):339-347. doi:10.1158/1940-6207.CAPR-09-0116

14. Yoseph BP, Klingensmith NJ, Liang Z, et al. Mechanisms of intestinal barrier dysfunction in sepsis. Shock. 2016;46(1):52-59. doi:10.1097/SHK.0000000000000565

15. Angus DC, van der Poll T. Severe sepsis and septic shock. $N$ Engl J Med. 2013;369(9):840-851. doi:10.1056/NEJMra1208623

16. Rhodes A, Evans LE, Alhazzani W, et al. Surviving sepsis campaign: international guidelines for management of sepsis and septic shock: 2016. Intensive Care Med. 2017;43(3):304-377.

17. Saleh AS. Early, goal-directed therapy for septic shock - a patient-level meta-analysis. N Engl J Med. 2017;377(10):994.

18. Bastarache JA, Matthay MA. Cecal ligation model of sepsis in mice: new insights. Crit Care Med. 2013;41(1):356-357. doi:10.1097/ CCM.0b013e318270e3ee

19. Ohsawa I, Ishikawa M, Takahashi K, et al. Hydrogen acts as a therapeutic antioxidant by selectively reducing cytotoxic oxygen radicals. Nat Med. 2007;13(6):688-694. doi:10.1038/nm1577

20. Ichihara M, Sobue S, Ito M, Ito M, Hirayama M, Ohno K. Beneficial biological effects and the underlying mechanisms of molecular hydrogen - comprehensive review of 321 original articles. Med Gas Res. 2015;5:12.

21. Klingensmith NJ, Coopersmith CM. The gut as the motor of multiple organ dysfunction in critical illness. Crit Care Clin. 2016;32 (2):203-212. doi:10.1016/j.ccc.2015.11.004

22. Ikeda M, Shimizu K, Ogura H, et al. Hydrogen-rich saline regulates intestinal barrier dysfunction, dysbiosis, and bacterial translocation in a murine model of sepsis. Shock. 2018;50(6):640-647. doi:10.1097/ SHK.0000000000001098

23. Rittirsch D, Huber-Lang MS, Flierl MA, Ward PA. Immunodesign of experimental sepsis by cecal ligation and puncture. Nat Protoc. 2009;4(1):31-36. doi:10.1038/nprot.2008.214

24. Baumgart DC, Dignass AU. Intestinal barrier function. Curr Opin Clin Nutr Metab Care. 2002;5(6):685-694. doi:10.1097/00075197200211000-00012

25. Levy MM, Macias WL, Vincent JL, et al. Early changes in organ function predict eventual survival in severe sepsis. Crit Care Med. 2005;33(10):2194-2201. doi:10.1097/01.CCM.0000182798. 39709.84

26. Liverani E, Rico MC, Yaratha L, Tsygankov AY, Kilpatrick LE, Kunapuli SP. LPS-induced systemic inflammation is more severe in P2Y12 null mice. J Leukoc Biol. 2014;95(2):313-323. doi:10.1189/ jlb. 1012518
27. Xie KL, Lian NQ, Kan YF, et al. iTRAQ-based quantitative proteomic analysis of the therapeutic effects of $\%$ hydrogen gas inhalation on brain injury in septic mice. Brain Res. 2020;1746:147003. doi:10.1016/j.brainres.2020.147003

28. Conway-Morris A, Wilson J, Shankar-Hari M. Immune activation in sepsis. Crit Care Clin. 2018;34(1):29-42. doi:10.1016/j. ccc.2017.08.002

29. Hotchkiss RS, Monneret G, Payen D. Sepsis-induced immunosuppression: from cellular dysfunctions to immunotherapy. Nat Rev Immunol. 2013;13(12):862-874. doi:10.1038/nri3552

30. Haak BW, Wiersinga WJ. The role of the gut microbiota in sepsis. Lancet Gastroenterol Hepatol. 2017;2(2):135-143. doi:10.1016/ S2468-1253(16)30119-4

31. Lin X, Shi S, Shi S. Sepsis leads to thyroid impairment and dysfunction in rat model. Tissue Cell. 2016;48(5):511-515. doi:10.1016/j. tice.2016.07.001

32. Powanda MC, Wannemacher RW, Cockerell GL. Nitrogen metabolism and protein synthesis during pneumococcal sepsis in rats. Infect Immun. 1972;6(3):266-271. doi:10.1128/IAI.6.3.266-271.1972

33. Orellana RA, Wilson FA, Gazzaneo MC, Suryawan A, Davis TA, Nguyen HV. Sepsis and development impede muscle protein synthesis in neonatal pigs by different ribosomal mechanisms. Pediatr Res. 2011;69(6):473-478. doi:10.1203/PDR.0b013e3182176da1

34. DeLano FA, Hoyt DB, Schmid-Schonbein GW. Pancreatic digestive enzyme blockade in the intestine increases survival after experimental shock. Sci Transl Med. 2013;5(169):169ra111. doi:10.1126/ scitranslmed.3005046

35. Schmid-Schonbein GW, Chang M. The autodigestion hypothesis for shock and multi-organ failure. Ann Biomed Eng. 2014;42 (2):405-414. doi:10.1007/s10439-013-0891-6

36. $\mathrm{Li} \mathrm{W,} \mathrm{Tao} \mathrm{S}, \mathrm{Wu} \mathrm{Q}, \mathrm{Wu} \mathrm{T}$, Tao R, Fan J. Glutamine reduces myocardial cell apoptosis in a rat model of sepsis by promoting expression of heat shock protein 90. J Surg Res. 2017;220:247-254. doi:10.1016/j.jss.2017.06.090

37. Briassouli E, Tzanoudaki M, Goukos D, et al. Glutamine may repress the weak LPS and enhance the strong heat shock induction of monocyte and lymphocyte HSP72 proteins but may not modulate the HSP72 mRNA in patients with sepsis or trauma. Biomed Res Int. 2015;2015:806042. doi:10.1155/2015/806042

38. Gaddnas F, Koskela M, Koivukangas V, et al. Markers of collagen synthesis and degradation are increased in serum in severe sepsis: a longitudinal study of 44 patients. Crit Care. 2009;13(2):R53. doi: $10.1186 / \operatorname{cc} 7780$

39. Shogan BD, Belogortseva N, Luong PM, et al. Collagen degradation and MMP9 activation by Enterococcus faecalis contribute to intestinal anastomotic leak. Sci Transl Med. 2015;7(286):286ra268. doi:10.1126/scitranslmed.3010658

40. Ting L, Rad R, Gygi SP, Haas W. MS3 eliminates ratio distortion in isobaric multiplexed quantitative proteomics. Nat Methods. 2011;8 (11):937-940. doi:10.1038/nmeth.1714

41. Yu N, Zhang S, Lu J, et al. Serum amyloid A, an acute phase protein, stimulates proliferative and proinflammatory responses of keratinocytes. Cell Prolif. 2017;50(3):e12320. doi:10.1111/cpr.12320

42. Tamamoto T, Ohno K, Goto-Koshino Y, Fujino Y, Tsujimoto H. Serum amyloid A uptake by feline peripheral macrophages. Vet Immunol Immunopathol. 2012;150(1-2):47-52. doi:10.1016/j. vetimm.2012.08.005

43. Zhou H, Chen M, Zhang G, Ye RD. Suppression of lipopolysaccharide-induced inflammatory response by fragments from serum amyloid A. J Immunol. 2017;199(3):1105-1112. doi:10.4049/jimmunol.1700470

44. Yu MH, Li X, Li Q, et al. SAA1 increases NOX4/ROS production to promote LPS-induced inflammation in vascular smooth muscle cells through activating p38MAPK/NF-kappaB pathway. BMC Mol Cell Biol. 2019;20(1):15. doi:10.1186/s12860-019-0197-0 
45. Okuda T, Higashi Y, Kokame K, Tanaka C, Kondoh H, Miyata T. Ndrg1-deficient mice exhibit a progressive demyelinating disorder of peripheral nerves. Mol Cell Biol. 2004;24(9):3949-3956. doi:10.1128/MCB.24.9.3949-3956.2004

46. Hosoi F, Izumi H, Kawahara A, et al. N-myc downstream regulated gene 1/Cap43 suppresses tumor growth and angiogenesis of pancreatic cancer through attenuation of inhibitor of kappaB kinase beta expression. Cancer Res. 2009;69(12):4983-4991. doi:10.1158/00085472.CAN-08-4882

47. Murakami Y, Watari K, Shibata T, et al. N-myc downstream-regulated gene 1 promotes tumor inflammatory angiogenesis through JNK activation and autocrine loop of interleukin-1alpha by human gastric cancer cells. J Biol Chem. 2013;288(35):25025-25037. doi:10.1074/jbc.M113.472068

48. Mollenhauer J, Holmskov U, Wiemann S, et al. The genomic structure of the DMBT1 gene: evidence for a region with susceptibility to genomic instability. Oncogene. 1999;18(46):6233-6240. doi:10.1038/ sj.onc. 1203071
49. Mollenhauer J, Herbertz S, Helmke B, et al. Deleted in malignant brain tumors 1 is a versatile mucin-like molecule likely to play a differential role in digestive tract cancer. Cancer Res. 2001;61 (24):8880-8886.

50. Rosenstiel P, Sina C, End C, et al. Regulation of DMBT1 via NOD2 and TLR4 in intestinal epithelial cells modulates bacterial recognition and invasion. J Immunol. 2007;178(12):8203-8211. doi:10.4049/ jimmunol.178.12.8203

51. Ueki K, Kondo T, Kahn CR. Suppressor of cytokine signaling 1 (SOCS-1) and SOCS-3 cause insulin resistance through inhibition of tyrosine phosphorylation of insulin receptor substrate proteins by discrete mechanisms. Mol Cell Biol. 2004;24(12):5434-5446. doi:10.1128/MCB.24.12.5434-5446.2004

\section{Publish your work in this journal}

Drug Design, Development and Therapy is an international, peerreviewed open-access journal that spans the spectrum of drug design and development through to clinical applications. Clinical outcomes, patient safety, and programs for the development and effective, safe, and sustained use of medicines are a feature of the journal, which has also been accepted for indexing on PubMed Central. The manuscript management system is completely online and includes a very quick and fair peer-review system, which is all easy to use. Visit http://www. dovepress.com/testimonials.php to read real quotes from published authors. 